\title{
Palestina-mandatet og historikerne
}

Når de skal beskrive hvordan britene overtok styringen av Palestina, støtter flere ledende historikere opp om et narrativ som stammer fra sionistbevegelsens høyrefløy, og som er stikk i strid med det som faktisk skjedde.

Av Per A. Christiansen, cand. philol. fra UiO med historie hovedfag og oppgaven Opprettelsen av Transjordan. Britisk minimalisme i Midtøsten 1919-1924. Han var Aftenpostens korrespondent i Midtøsten 1984-1989 og 2005-2009.

I KJølvannet AV Første verdenskrig fikk Storbritannia mandat fra det nystiftede Folkeforbundet til å styre «Palestina» fram mot selvstendighet, uten at dette landets geografiske begrensning ble nærmere presisert.

Da mandatet trådte i kraft 29. september I923, omfattet det områder både vest og øst for Jordanelven, henholdsvis Palestina og Transjordan, under hver sin administrasjon. Måten denne inndelingen skjedde på, er de senere år blitt beskrevet av flere internasjonalt anerkjente historikere, i temmelig likelydende vendinger, som en form for oppdeling av Palestina.

Eugene Rogan gir følgende beskrivelse:

The territory [Transjordan] initially was awarded to Great Britain as part of the Palestine mandate. The decision to sever Transjordan from Palestine [was] formalized in $1923 .{ }^{1}$

Joseph Nevo skriver at "Transjordan was separated from Palestine”. ${ }^{2}$ Baruch Kimmerling og Joel S.
Migdal hevder at "the British did not separate [Transjordan] from Palestine until I922."3 Arthur Goldschmidt jr. omtaler Transjordan som "the part of Palestine east of the Jordan River".4 Og Jonathan Schneer mener at britenes daværende koloniminister Winston Churchill "carved Transjordan out of Palestine". 5

Slik disse historikerne presenterer utviklingen, var altså Transjordan opprinnelig en del av Palestina. Men den britiske regjering, med Churchill som pådriver, valgte å dele opp området og skille ut Transjordan som egen administrativ enhet.

Problemet med en slik fremstilling er at den stiller saken på hodet.

Som Bernard Wasserstein har påpekt:

$[O] n$ any dispassionate reading of the Foreign Office documents and related contemporary materials, the historical record showed that Palestine was not amputated, but enlarged, that Transjordan was not lopped off, but added to the mandate. ${ }^{6}$ 


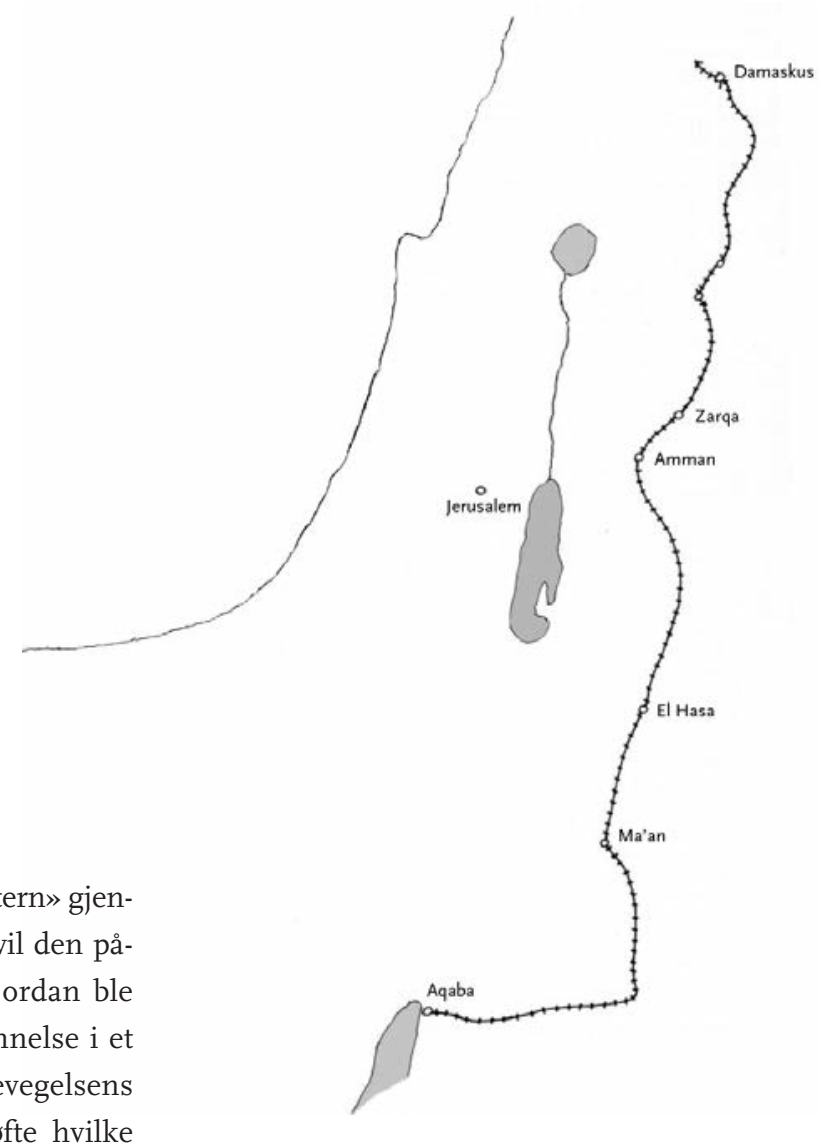

Denne artikkelen vil foreta en slik «nøktern» gjennomgang av kildematerialet. Dernest vil den påvise hvordan påstanden om at Transjordan ble «skilt ut» fra Palestina, har sin opprinnelse i et narrativ som stammer fra sionistbevegelsens høyrefløy. Avslutningsvis vil den drøfte hvilke mulige følger en slik feilaktig oppfatning kan få i dagens situasjon.

Verdens sionistorganisasjon ønsket i 1919 at Palestinas østgrense skulle trekkes like vest for Hedjaz-jernbanen.

\section{Balfour-erklæringen}

Da utenriksminister James Balfour 2. november I9I7 erklærte at den britiske regjering så med velvilje på planene om å opprette et jødisk nasjonalhjem «i Palestina», var dette området ikke klart definert.

Ifølge datidens utgave av Encyclopedia Britannica var Palestina "a geographical name of rather loose application”, selv om

it may be said generally to denote the southern third of the province of Syria. Except in the west, where the country is bordered by the Mediterranean Sea, the

limit of this territory cannot be laid down on the map as a definite line.?

En nåtidig autoritet, professor Gideon Biger ved universitetet i Tel Aviv, understreker på sin side at selv om østgrensen aldri lå fast, tjente Jordandalen gjennom århundrenes løp "often [...] as a political border."

Nettopp et slikt politisk og administrativt skille fantes da Balfour kom med sin erklæring. Under Det osmanske riket tilhørte området vest for Jordandalen den såkalte Beirut-provinsen, eller 
Vilayet Beirut, riktignok med Jerusalem-området som eget distrikt (sanjaq) direkte underlagt Istanbul fra 1872 . Området øst for Jordandalen tilhørte Vilayet Suriyya og ble styrt fra Damaskus.

Mot slutten av den osmanske perioden ble Palestina stadig nærmere knyttet til Europa. Landet ble trukket inn i en vestlig markedsøkonomi som først og fremst påvirket kyststripen, men også de områdene som var lettest tilgjengelige derfra. Parallelt skjedde det fra midten av I80o-tallet en økonomisk utvikling øst for Jordandalen. Men denne utviklingen ble inspirert og styrt fra Damaskus, og førte til at området ble sterkere knyttet til den syriske hovedstaden, blant annet gjennom etableringen av jernbaneforbindelsen til Hijaz. ${ }^{9}$

Det administrative skillet mellom områdene vest og øst for Jordandalen skulle vise seg å bli opprettholdt da britene overtok kontrollen over denne delen av Midtøsten.

\section{Det arabiske opprøret}

Storbritannia kom for fullt inn i regionen under Første verdenskrig, da London-regjeringen støttet et arabisk opprør mot Det osmanske riket. Opprøret ble ledet av sharif Husayn ibn Ali, som vendte seg imot sine osmanske herskere i Istanbul mot et britisk løfte om at araberne etter krigen skulle få selvstendighet i et uklart definert område.

I I9I6 utnevnte Husayn seg selv til konge over Hijaz, den delen av Den arabiske halvøy som grenser mot Rødehavet, og som den gang strakte seg nordover til byen Maan, I5 mil nord for Aqaba i det nåværende Jordan. Han fikk organisert en hærstyrke, Den arabiske hær, som under ledelse av hans sønn Faysal ibn Husayn rettet stadige angrep mot de osmanske styrkene i området. Angrepene fant for en stor del sted langs Hijaz-jernbanen, som var ment å skulle bringe muslimske pilegrimer fra Damaskus til Mekka, men som aldri nådde lenger enn til Medina.

Mens Den arabiske hær trengte nordover i området øst for Jordandalen, opererte en britisk styrke under ledelse av general Edmund Allenby i vest. Den 9. desember I9I7 rykket Allenby inn i Jerusalem, før han fortsatte videre nordover langs kysten. Et knapt år senere, I. oktober I9I8, erobret Faysal og hans arabiske styrker Damaskus.

Etter hvert som de osmanske styrkene ble presset tilbake, opprettet britene tre soner for administrasjon av okkupert fiendtlig territorium. To av disse sonene lå vest for Jordandalen, den tredje omfattet områder i øst, det vil si fra Jordandalen og så langt øst og nord som det i praksis var mulig å drive noen form for administrasjon. ${ }^{\text {Io }}$

I kjølvannet av den osmanske tilbaketrekningen fra Syria overlot britene ansvaret for området øst for Jordandalen til Den arabiske hær. ${ }^{\text {II }} \mathrm{Da}$ Det osmanske riket 30. oktober undertegnet en våpenstillstandsavtale, hadde amir Faysal allerede etablert sin egen administrasjon i Damaskus. Han fikk også organisert en syrisk nasjonalkongress som 20. juni I9I9 vedtok å opprette et fritt og uavhengig Syria under hans ledelse.

Mens Transjordan fram til Første verdenskrig var en del av den osmanske Damaskus-provinsen,

\section{Sykes-Picot-avtalen delte de davorende osmanske områdene i Midtøsten inn i innflytelsessfoerer.}

hadde altså araberne ved slutten av krigen overtatt styringen av dette området, som strakte seg sørover til Hijaz. Faysal kom imidlertid i en stadig vanskeligere klemme mellom arabiske nasjonalister og den franske regjeringen, som med støtte i Sykes-Picot-avtalen av ı9ı6 gjorde krav på å øve direkte innflytelse i Syria. 


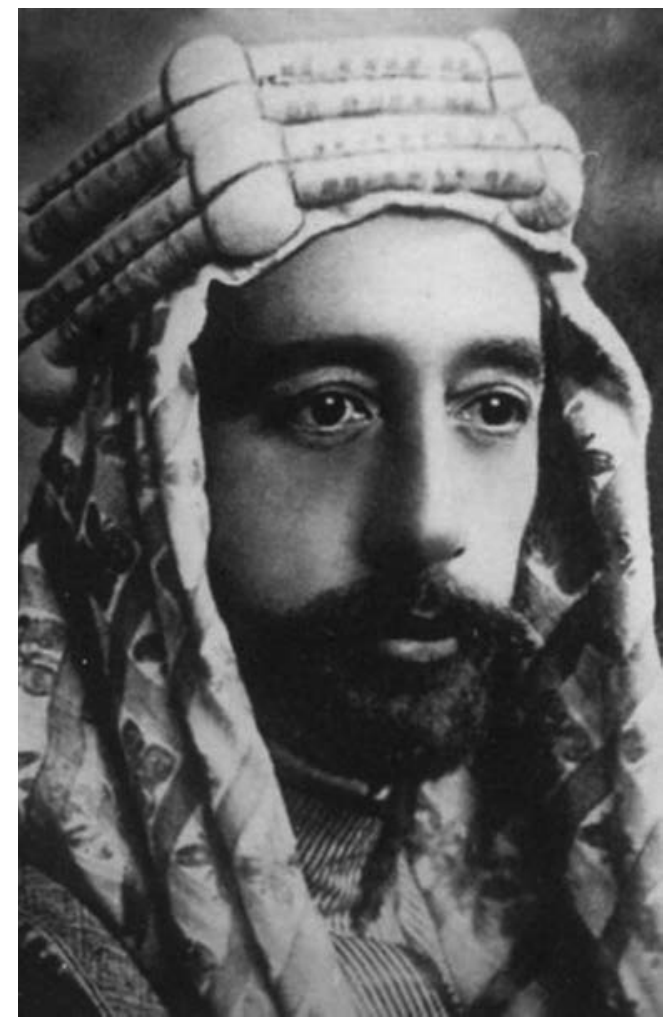

Amir Faysal ibn Husayn etablerte seg i Damaskus i 1918.

Denne fransk-britiske avtalen delte de daværende osmanske områdene i Midtøsten inn i innflytelsessfærer. Frankrike var tiltenkt de områdene som i dag utgjør statene Libanon og Syria, mens britene skulle få det senere Palestina, Transjordan og Irak. For å sikre seg politisk ryggdekning sammenkalte Faysal på ny nasjonalkongressen, som 7. mars I920 tilbød ham tronen i Syria. Dagen etter ble et kongedømme erklært opprettet, men det viste seg å få en svært kortvarig levetid. Franskmennene rykket inn, beseiret de syriske styrkene i et slag 24. juli, oppløste kongedømmet og sendte Faysal i eksil. ${ }^{22}$

\section{Britisk uro}

Dermed oppsto det en helt ny situasjon. Så lenge Faysal satt i Damaskus, styrte han et rike som i hvert fall på papiret strakte seg tvers over grensen mellom den franske og den britiske interessesfæren, slik den var blitt trukket opp i Sykes-Picotavtalen, og som i sør grenset mot sharif Husayns kongedømme i Hijaz. Etter Faysals nederlag hadde den såkalte «Damaskus-staten» kommet under fransk kontroll, og britene fryktet at Frankrike skulle forsøke å gjøre sin innflytelse gjeldende også øst for Jordandalen, det vil si i den britiske interessesfæren.

Denne uroen ble først og fremst uttrykt av britenes første høykommissær i Jerusalem, Sir Herbert Samuel. Han meldte at franskmennene

have appointed new Governors to Hauran, Salt, etc, and have summoned all Sheikhs as far as Kerak.

Samuel kunne videre fortelle om en fransk propagandakampanje "throughout TransJordania” og at lokale ledere øst for Jordandalen hadde bedt britiske myndigheter klargjøre hvorvidt de skulle adlyde ordrer fra Damaskus. ${ }^{\mathrm{I3}}$

Det er sannsynlig at Sir Herbert her ikke bygde på annet enn rykter som svirret i Jerusalem. Men det er helt klart at britene tok trusselen om mulig fransk innblanding alvorlig. Dette fremgår av flere uttalelser og erklæringer i perioden etter 28. juli, da Faysal forlot Damaskus.

Den 6. august mottok for eksempel høykommissariatet i Jerusalem et telegram fra London der Foreign Office

suggest that you should let it be known forthwith that in area south of the [Sykes-Picot] line we will not admit French authority and that our policy is for this area to be independent, but in closest relation with Palestine. $^{14}$

På dette tidspunkt hadde det nystiftede Folkeforbundet opprettet et nytt system for administrasjonen av områder av Det osmanske riket som 
de allierte hadde erobret, det såkalte mandatsystemet. Det vil si at de allierte stormaktene - i praksis Frankrike og Storbritannia - på Folkeforbundets vegne skulle styre områdene fram mot selvstendighet.

På fredskonferansen i San Remo i april I920 hadde britene fått ansvar for «Mesopotamia» og «Palestine». De nøyaktige grensene for disse områdene skulle senere avgjøres av de allierte partnerne.

Britiske myndigheter var selvsagt klar over at disse to mandatområdene ikke grenset mot hverandre. Faysals fall aktualiserte spørsmålet om

\section{Verdens sionistorganisasjon hadde allerede tatt til orde for at Palestinas østgrense skulle trekkes øst for Jordandalen.

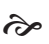

hva som skulle skje med det mellomliggende området, som britene på dette tidspunkt konsekvent omtalte som «Transjordan», både i offisielle dokumenter, i intern korrespondanse og i private brev.

Samtidig hadde Verdens sionistorganisasjon allerede tatt til orde for at Palestinas østgrense skulle trekkes øst for Jordandalen. I en strengt fortrolig erklæring til den britiske regjering 3. februar I9I9 fremmet organisasjonen en serie forslag som den ønsket skulle presenteres for fredskonferansen i Versailles.

I et vedlegg til erklæringen presiserte organisasjonen hvor den ønsket at Palestinas østgrense skulle trekkes:

In the East a line close to and West of the Hedjaz Railway terminating in the Gulf of Akaba. ${ }^{15}$

Senere tok sionistlederen Chaim Weizmann opp dette kravet i flere henvendelser til den britiske regjeringen. ${ }^{16}$ Men alle slike forsøk på å få skjøvet Palestinas grense østover, ble avvist. Begrunnelsen var i hvert tilfelle av militær karakter og ble fremført av War Office.

\section{Militær motstand}

Sett fra et strategisk synspunkt var det området vest for Jordandalen som var viktigst for Storbritannia. Britenes interesser i området var i første rekke knyttet til forsvaret av Suezkanalen, og den militære ekspertisen mente at dette området lot seg forsvare uten at britiske styrker behøvde å krysse Jordandalen.

I et memorandum til regjeringen i juni I9I9 skrev således oberstløytnant W. H. Gibbon på vegne av generalstaben at

The Jordan can be held by a small force [...]. The strategic defence of Palestine is much simpler than that of Mesopotamia [...] where there are no natural boundaries such as are afforded in Palestine by the sea on the left flank and the Jordan on the right. ${ }^{17}$

Forsvarsledelsen - og dermed den britiske regjeringen - sto fast på denne holdningen helt fram til Palestina-mandatet trådte i kraft i I923. Dette til tross for at Sir Herbert Samuel varslet om mulig fransk innblanding i Transjordan og tok til orde for at området burde «inkluderes» i Palestina. I et brev til utenriksminister Lord Curzon skrev han således at han var

deeply convinced that we shall be making a grave error of policy if we do not now include Trans-Jordania in Palestine. It will certainly result in anarchy or French Control across the border. ${ }^{18}$

Svaret var utvetydig. Regjeringen var

opposed to military occupation of Trans-Jordania. In any case War Office definitely refuse to furnish troops 


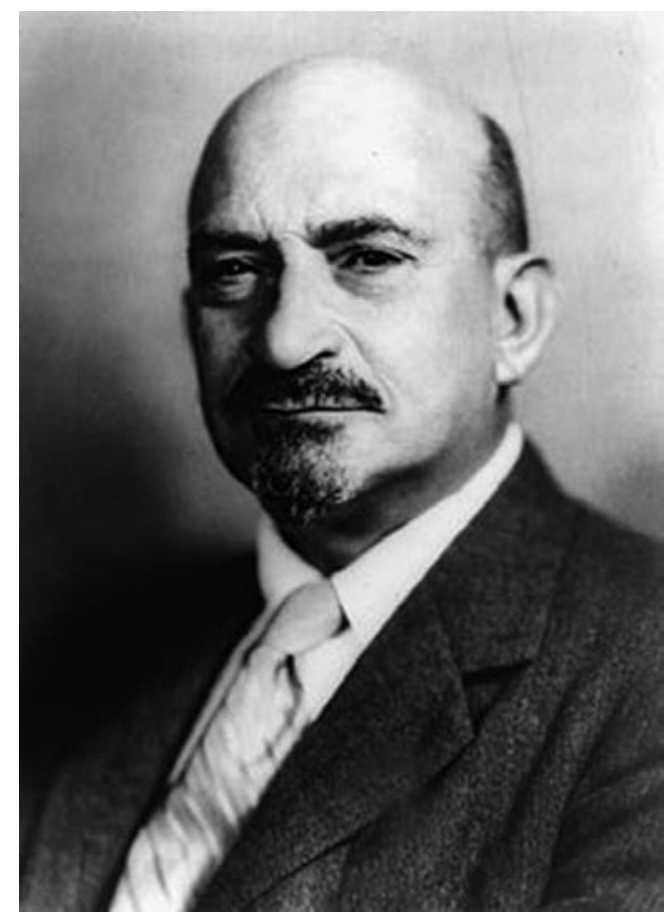

Sionisten Chaim Weizmann stilte grensekrav.

or undertake responsibility for subsequent commitments which might result. ${ }^{19}$

Høsten I920 utdypet forsvarsdepartementet dette $i$ et memorandum til utenriksdepartementet. Det var ført i pennen av Herbert James Creedy, som var krigs- og luftfartsminister Winston Churchills privatsekretær:

[R]egarding the case for the presence in Transjordania of a small force of British or Indian troops, I am to say that [...] the Army Council are consistently opposed to the dispersal of force in whatever form it may be advocated. ${ }^{20}$

Spørsmålet om Palestinas østgrense ble også tatt opp i Underhuset, blant annet på bakgrunn av at britene hadde opprettet et generalkommissariat og en administrasjon i Jerusalem. Den 28. juli
I920, samme dag som amir Faysal forlot Damaskus, ble det reist spørsmål om

how far and in what places the administrative authority of the government of Palestine extends to the east of the River Jordan. ${ }^{21}$

Lord Privy Seal Andrew Bonar Law svarte på statsministerens vegne, og fastslo kategorisk:

The administrative authority of the Government of Palestine does not extend to the east of the River Jordan.22

Om østgrensen således i grove trekk var fastsatt, gjensto spørsmålet om hva britene skulle gjøre med tomrom som hadde oppstått etter at franskmennene sparket Faysal ut av Damaskus. Dette spørsmålet ble i første omgang overlatt til regjeringens interdepartementale Palestina-komite.

På et møte I7. august I920 skisserte komiteen tre mulige løsninger på problemet med området mellom Palestina og Mesopotamia: Den første muligheten var at britene kunne erklære at de to områdene var "coterminous", det vil si at de grenset mot hverandre, men uten å trekke opp noen konkret grenselinje. Den andre muligheten var at de kunne la Mesopotamia strekke seg helt vest til Palestina, det vil i praksis si til Jordandalen. Det tredje alternativet var at de kunne trekke opp rimelige grenser for de to mandatene, slik at det mellomliggende området kunne bli betraktet som et britisk interesseområde, men ikke som mandatterritorium. ${ }^{23}$

Komiteen anførte innvendinger mot alle de tre mulige løsningene og anbefalte ingen av dem. Blant annet påpekte den at det var umulig å finne en løsning som kunne tilfredsstille Folkeforbundet og samtidig være i overensstemmelse både med britenes forpliktelser ifølge Sykes-Picot-avtalen og deres løfter til kong Husayn av Hijaz. ${ }^{24}$ 
Inntil dette spørsmålet var avklart, måtte den britiske regjeringen falle ned på en midlertidig løsning. Denne ble skissert i en instruks fra Foreign Office til den britiske delegasjonen i Paris i slutten av september. Her ble det blant annet påpekt at

His Majesty's Government are already treating "Trans-Jordania" as separate from the Damascus state, while at the same time avoiding any definitive connection between it and Palestine, thus leaving the way open for the establishment there, should it become advisable, of some sort of independent Arab Government, perhaps by arrangement with King Hussein or other Arab chiefs concerned. 25

Selv om problemet ennå ikke var løst, skisserte det britiske utenriksdepartementet her utkastet til det som temmelig nøyaktig et halvt år senere skulle bli det endelige vedtaket i saken.

\section{Kairo-konferansen}

I begynnelsen av januar I92I overtok Winston Churchill ledelsen av kolonidepartementet, og han gikk straks i gang med å legge planer for Midtøsten. For å få konkretisert disse besluttet han å reise til Kairo, hvor han ville konferere med de fremste britiske myndighetspersonene i området. På vei hjem planla han å gjøre et opphold i Jerusalem for å drøfte Palestina-politikken med høykommissær Sir Herbert Samuel.

Kairo-konferansen ble holdt fra I2. til 30. mars I92I. Den omhandlet et bredt spekter av spørsmål tilknyttet britenes fremtidige militære, administrative og politiske nærvær i regionen. Når det gjelder hva som skulle skje med Transjordan, ga konferansen sin tilslutning til et memorandum som på forhånd var utarbeidet i Foreign Office, og som fastslo at

If [His Majesty's Government] wish to assert their claim to Trans-Jordan and to avoid raising with other Powers the legal status of that area, they can only do so by proceeding upon the assumption that TransJordan forms part of the area covered by the Palestine mandate. ${ }^{26}$

Med andre ord: Bare ved å late som om Transjordan utgjorde en del av det palestinske mandatområdet, kunne britene skaffe seg legitimitet $i$ området uten å gå tilbake til sine alliansepartnere og fremforhandle nye mandatbetingelser.

Samtidig var regjeringen klar over at mandatet - med utgangspunkt i Balfour-erklæringen - påla britene å legge forholdene til rette for opprettelse av "et jødisk nasjonalhjem i Palestina". Memorandumet henviste imidlertid til de løfter britene hadde gitt sharif Husayn vedrørende støtte til arabisk selvstendighet. Og det fastslo at "Palestine and Trans-Jordan do not, therefore, stand upon quite the same footing." ${ }^{27}$ Følgelig anbefalte det

setting up in Trans-Jordan a political system somewhat different from that in force on the other side of the [Jordan] River. If British promises are to stand, this system must be Arab in character. ${ }^{28}$

Denne anbefalingen ble nedfelt i mandatet, slik det ble endelig vedtatt av Folkeforbundet den 24 . juli I922. Paragraf 25 vedrører området øst for Jordanelven og fastslår at mandatmakten, med samtykke fra Folkeforbundets råd,

shall be entitled [...] to postpone or withhold application of such provisions of this mandate as he may consider inapplicable to the existing local conditions. ${ }^{29}$

To måneder senere sendte britene et memorandum til Folkeforbundet der de redegjorde for hvilke bestemmelser i mandatet som ikke skulle gjelde øst for Jordandalen, nemlig de som omhandlet opprettelse av et jødisk nasjonalhjem, 


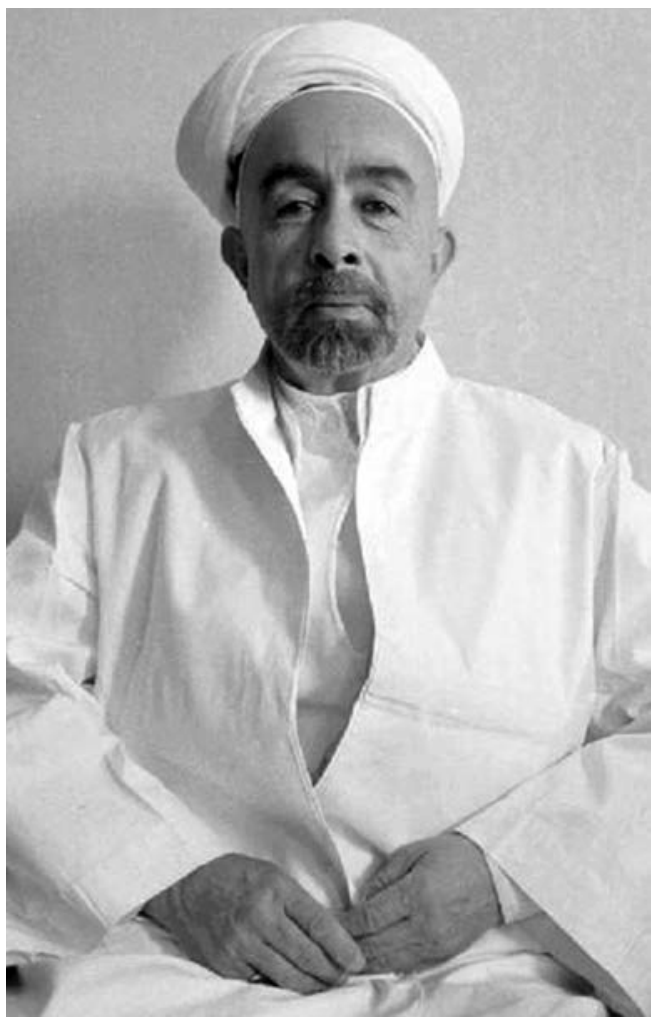

Amir Abdullah bin Husayn - «guvernør» av Transjordan i 1921.

jødisk innvandring, bruk av hebraisk som offisielt språk og lignende. ${ }^{\circ}$

Samtidig som Kairo-konferansen pågikk, hadde Faysals eldre bror, amir Abdullah ibn Husayn, beveget seg nordover i Transjordan i spissen for en styrke på 500 væpnede menn. . $^{\text {I }}$ Hans erklærte mål var å gjenerobre tronen i Damaskus på familiens vegne.

Britene kunne ikke la ham angripe franskmennene fra et område som hørte til den britiske innflytelsessfæren. Fordi War Office blankt motsatte seg å sende soldater til Transjordan, kunne de heller ikke fjerne Abdullah med makt. Løsningen ble funnet da Churchill fortsatte til Jerusalem, hvor han hadde tre møter med Abdullah. De ble da enige om at amiren skulle overta som «guvernør»av Transjordan, i første omgang for en periode på seks måneder, og med en britisk rådgiver ved sin side. Betingelsen var at han skulle oppgi forsøket på å gjenerobre brorens trone i Damaskus. ${ }^{2}$

Denne i utgangspunktet midlertidige løsningen skulle vise seg å bli svært permanent; 90 år senere sitter Abdullahs oldebarn, kong Abdullah II, fortsatt på tronen i Det hashemittiske kongedømmet Jordan.

\section{Revisjonistene}

Når Bernard Wasserstein påpeker at Palestina "ikke ble amputert, men utvidet",33 har han altså sitt på det tørre. Men hvordan kan fremtredende historikere ta så grundig feil på dette punktet? Her er det naturlig å starte med et israelsk narrativ.

Kravet fra Den sionistiske verdensorganisasjon i I9I9 om at Palestinas østgrense skulle gå vest for og parallelt med Hijaz-jernbanen, betydde i praksis at sionistene ville ha kontroll over Jordandalen og de nærmeste høydedragene øst for denne, et belte med en bredde på et par mil.

Da dette kravet straks ble avvist av britene, vakte det umiddelbart ingen sterke reaksjoner på sionistisk hold. Noen år senere ble det imidlertid reist på ny, og med full styrke, av høyrefløyen innen sionistorganisasjonen. Forgrunnsskikkelsen her var Vladimir (Zeev) Jabotinsky. Han krevde en mer pågående politikk, spesielt overfor den britiske mandatmakten, og brøt med sionistenes offisielle linje, den såkalte «praktiske sionisme». Den 25. april I925 dannet han og hans tilhengere Forbundet av revisjonistiske sionister. 34 På selve stiftelsesmøtet erklærte han at ett av målene for den nye organisasjonen var "virkeliggjørelsen av en stat med et jødisk flertall på begge sider av Jordanelven." 35

Kravet ble presisert i et dikt Jabotinsky skrev i I930, "Jordans venstre bredd", der elven ble beskrevet som Eretz Israels «pilar» eller «ryggrad». Refrenget “Jordan har to bredder. Denne er vår, og 
det er den [andre] også” ble ett av revisjonistenes sentrale slagord. ${ }^{6}$ Revisjonistene fikk senere sin egen ungdomsorganisasjon, Betar, og sine væpnede styrker, Irgun Zvai Leumi (Den nasjonale militære organisasjon). Irguns symbol var en hånd som holdt et gevær og en bajonett over et kart som viste mandatområdet Palestina på begge sider av Jordan, og med slagordet «Bare slik».

Symbolet ble senere overtatt av Irguns politiske avkom, Herut-partiet, bare med den forandring at slagordet ble forandret til «Hjemland og frihet».37

Partier som ideologisk og/eller organisatorisk springer ut av Herut, framfor alt Likud, har de siste tiårene spilt en ledende rolle i israelsk politikk. ${ }^{38}$ Helt til begynnelsen av I980-tallet fastholdt revisjonistene at området øst for Jordan tilhører Eretz Israel, det vil si Israelsfolkets land.

Ingen av Heruts arvtakere støtter i dag offisielt dette kravet. Men forestillingen om at jødene i I92I ble frarøvet størsteparten av det området der de skulle bygge sitt nasjonalhjem, lever likevel videre. Den går igjen i offentlig debatt, i leserspalter og i politisk diskurs. Og da snakker israelerne ikke bare om den smale landstripen øst for Jordanelven som sionistorganisasjonen opprinnelig ønsket å sikre seg, men om hele det området som i dag utgjør kongedømmet Jordan.

Således skriver tidligere forsvars- og utenriksminister for Likud, Moshe Arens, følgende i avisen Haaretz i 20I2:

In 1921, Winston Churchill, the newly appointed British colonial secretary, hurried from London to Jerusalem and offered Emir Abdullah, the son of Sharif Hussein of Mecca, the territory of Palestine east of the Jordan River. That was three-quarters of the area that had been intended to serve as the national home of the Jewish people. 39

Blant dem som har støttet mest iherdig opp om denne forestillingen, er tidligere statsminister

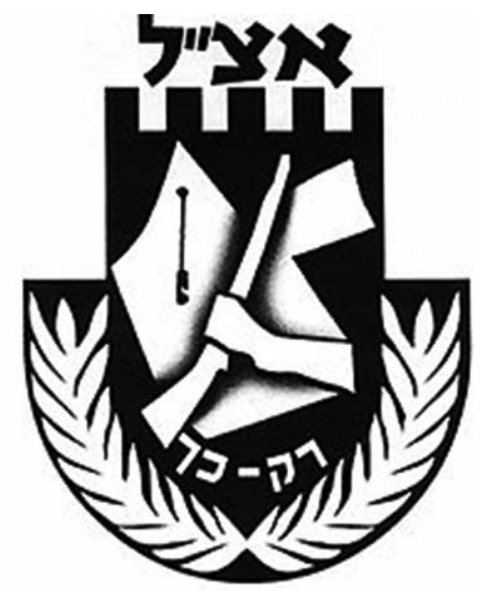

Irguns symbol med slagordet «Bare slik».

Ariel Sharon. Fram til han i 2006 ble rammet av slag, var Sharon den fremste talsmannen for den påstand at «Jordan er Palestina». Tilhengerne av dette synet mener det palestinske problemet, framfor alt flyktningproblemet, må finne sin løsning øst for Jordandalen, om nødvendig ved at kongedømmet avvikles.

I sin selvbiografi fra I989 skriver Sharon at

Originally Palestine had included Jordan. The two had only been separated in 1922 by the British, who gave what was then known as Transjordan to their allies, the Hashemite royal family from Saudi Arabia [sic]. $4^{\circ}$

Synspunktet støttes av det israelske utenriksdepartementet, som i en artikkel om Jabotinsky skriver at

Great Britain severed almost $80 \%$ of Mandate Palestine originally designated for a Jewish Homeland to create Transjordan (1922).41

Men britene hadde aldri hatt til hensikt å la området øst for Jordandalen inngå i det jødiske nasjonalhjemmet. Og når Arens og andre hevder at 
tre fjerdedeler av det opprinnelige Palestina lå i øst, må de dessuten ta utgangspunkt i grensene og flateinnholdet til dagens jordanske kongedømme. Disse grensene ble imidlertid først etablert flere år etter at mandatet trådte i kraft:

Under press fra Saud-klanens krigere gikk nemlig kongedømmet Hijaz i oppløsning, og distriktene Maan og Aqaba ble den 24. juni I925 overført til Transjordan. Den 2. november samme år ble grensen mellom Transjordan og Nejd (i den blivende staten Saudi-Arabia) etablert. Og grensen mot Irak ble først trukket opp 28. april I928.42 bruke dagens grenser for å beskrive situasjonen $\mathrm{i}$ I922, er dermed helt feil.

Denne anakronistiske måten å beskrive situasjonen på, går igjen på det israelske utenriksdepartementets hjemmeside i dag. Der blir det under overskriften "Separation of Transjordan I922" gjengitt et kart som viser dagens grenser mot Saudi-Arabia og Irak.43

\section{Gjennomslagskraft}

Når de skriver at Transjordan ble "sever[ed]", "separated" eller "carved [...] out of Palestine“, er historikerne Rogan, Nevo, Goldschmidt og Schneer altså helt på linje med dette israelske narrativet. Det samme gjelder sosiologen Kimmerling og statsviteren Migdal.

Hva kan være årsaken til at de på dette punktet stiller saken slik på hodet?

Ingen av dem kan mistenkes for å ville løpe den israelske høyresidens ærend. Tvert imot har de alle levert solide og anerkjente bidrag til historieforskningen i Midtøsten. Når de likevel tar feil, kan det bare skyldes at det israelske narrativet gjennom årenes løp har fått en betydelig gjennomslagskraft. Fra å være en av den sionistiske høyresidens kampsaker, er det i dag blitt en allment akseptert fremstilling. Dette understrekes ved at de historikerne som her er nevnt, hører hjemme i hver sin akademiske institusjon: Joseph
Nevo er professor ved Universitetet i Haifa. Eugene Rogan er forsker ved St. Anthony's College i Oxford. Goldschmidt var professor (nå emeritus) ved Penn State University.44 Jonathan Schneer er professor ved Georgia Institute of Technology i Atlanta. Både Kimmerling (død i 2007), som var professor ved Det hebraiske universitet i Jerusalem, og Migdal, som er professor

\section{2 \\ Ingen av historikerne kan mistenkes for $\stackrel{a}{\circ}$ ville løpe den israelske høyresidens orend. Tvert imot.}

ved University of Washington i Seattle, har stilt seg svært kritiske til Israels politikk i konflikten med palestinerne.

Det er mulig disse forfatterne kan ha funnet støtte for sin fremstilling ved å gå tilbake og granske sluttresultatene av den prosess som førte frem til innlemmelsen av Transjordan i Palestinamandatet. Det gjelder for det første selve mandatteksten, slik den ble endelig utformet, og for det andre kart av den typen som er gjengitt på det israelske utenriksdepartementets hjemmeside. Men de har åpenbart ikke tatt for seg den prosessen som ga et slikt resultat. Og de klarer åpenbart heller ikke å skille mellom «Palestinamandatet» og Palestina.

To av de verkene der den feilaktige fremstillingen gjengis (Nevo og Schneer), beskriver i noen detalj omstendighetene omkring opprettelsen av mandatet og/eller Transjordans tilblivelse, og de burde ha klart å fange opp den del av kildematerialet som vedrører Kairo-konferansen og dens følger.

Når det gjelder den boken av Rogan som her er sitert, tar den for seg arabisk historie fra opprettelsen av Det osmanske riket og fram til i dag. Det kan hevdes at det i slike oversiktsverk ikke 
stilles de samme krav til bruk av førstehåndskilder. På den annen side har Rogan tidligere skrevet et grundig verk om nettopp utviklingen av Transjordan i perioden omkring osmanerrikets sammenbrudd.45 Her omtaler han blant annet områdets tilknytning til amir Faysals syriske rike fram til franskmennenes maktovertakelse i Damaskus. Men han slipper tråden før han kommer til Kairo-konferansen i mars I92I.

Andre historikere, som har fulgt prosessen med utarbeidelse av mandatet fram til at den endelige teksten ble vedtatt, har klart å gi en riktig beskrivelse. Blant disse er Mary C. Wilson ${ }^{4}$ og ikke minst Aaron S. Klieman. 47 De publiserte sine verk flere år før bøkene med villedende beskrivelser så dagens lys - Wilsons bok kom ut i ig87, Kliemans allerede i I970.

\section{Politiske overtoner}

Sett fra en rent akademisk synsvinkel er det selvsagt kritikkverdig når historikere gir misvisende beskrivelser av et hendelsesforløp. Seriøse forskere plikter å ha oversikt over så vel kildemateriale som tidligere publisert litteratur.

Saken har også klare politiske overtoner. Det er ikke vanskelig å tenke seg situasjoner der spørsmålet om jødenes «tap» av «tre fjerdedeler» av deres planlagte nasjonalhjem får ny aktualitet.

Hvis hashemittenes trone i Jordan skulle begynne å vakle, eller endog falle, vil samtlige av kongedømmets naboer bli fristet til å forsvare egne territoriale og sikkerhetsmessige interesser. Da kan det igjen bli reist krav i Israel om at sionistene må skaffe seg kontroll over områder på østsiden av Jordandalen. Dette var noe som ble seriøst drøftet $\mathrm{i}$ israelske regjeringskretser $\mathrm{i}$ I $68,4^{8}$ og det kan på ny bli aktuelt, spesielt dersom også land som Irak og Saudi-Arabia prøver å sikre seg deler av Jordan.

Hvis og når spørsmålet om opprettelse av en palestinsk stat på Vestbredden og Gazastripen igjen blir aktuelt, kan israelerne på den annen side hevde at de allerede har gitt avkall på «tre fjerdedeler» av sitt opprinnelige nasjonalhjem, og at de ikke kan forventes å oppgi mer.

Og endelig kan en feilaktig oppfatning av hva som faktisk skjedde da mandatet ble opprettet, bidra til å støtte opp om dem som i likhet med tidligere statsminister Ariel Sharon fortsatt mener at «Jordan er Palestina», og at det palestinske problemet må finne sin løsning der.

Spesielt i situasjoner der historiske framstillinger kan bli tema i løpende politiske stridigheter, er det påtvingende nødvendig at forskerne viser forsiktighet og ikke uten videre aksepterer en av partenes narrativ, uansett hvor alminnelig akseptert dette måtte være.

Det har ikke skjedd i dette tilfellet.

\section{- $f$ •}

I Rogan, Eugene: The Arabs. A History. Paperback edition. London: Penguin Books, 2010, s. 228.

2 Nevo, Joseph: King Abdallah and Palestine. A Territorial Ambition. London: MacMillan, I996, s. 3.

3 Kimmerling, Baruch og Joel S. Migdal: The Palestinian People. A History. Cambridge, Mass: Harvard University Press, 2003, s. 25 .

4 Goldschmidt, Arthur jr. og Lawrence Davidson: A Concise History of the Middle East. Tenth edition. Boulder, Col: Westview Press, 2012, s. I95. Formuleringen er identisk med den som finnes i verkets annen utgave fra $198_{3}$, og later derfor til å ha stått uforandret gjennom tre tiår.

5 Schneer, Jonathan: The Balfour Declaration. The Origins of the Arab-Israeli Conflict. Paperback edition. London: Bloomsbury, 20II, s. 374 .

6 Wasserstein, Bernard: “The British Mandate in Palestine: Myths and Realities", i Middle East Lectures, Number One. Tel Aviv: The Moshe Dayan Center for Middle Eastern and African Studies, I995, s. 3I.

7 Encyclopedia Britannica, Eleventh Edition, I9I0-II, ss. 600-60I.

8 Biger, Gideon: “Names and Boundaries of Eretz-Israel”, i Ruth Kark (ed): The Land That Became Israel: Studies in Historical Geography. London: Yale University Press, I990, S. 4 .

9 Owen, Roger: The Middle East in the World Economy $1800-$ 1914. London: Methuen, I98I, passim. 
IO Public Record Office WO I53/IO45. Approx borders of OETA, 20 January I9I9. Abujaber, Raouf Sa'ad: Pioneers Over Jordan. The Frontier Of Settlement In Transjordan, 18501914. London: I. B. Tauris, I989, passim.

II Rogan, Eugene L.: Frontiers of the State in the Late Ottoman Empire: Transjordan 1850-1921. London: Cambridge Middle East Studies, I999, s. 242.

I2 Se blant annet Yapp, M. E.: The Making of the Modern Near East 1792-1923. London: Longman, I987.

I3 Butler, Rohan, M.A. og J.P.T. Bury, M.A. (red.): Documents on British Foreign Policy 1919-1939, Volume XIII. London: HSO I963. Nos 300, 301, 308.

I4 PRO FO 37I/5I2I, FO to Samuel 6 August I920.

I5 Statement of the Zionist organisation regarding Palestine. 3 February i9i9. Samuel Papers DS I49, Middle East Centre, St. Anthony's College, Oxford.

I6 India Office L/P\&S/II/I70. P2478/20. Weizmann to Curzon, 2 February 1920.

I7 PRO CAB 2I/I53. Gribbon to War Cabinet, I2 June I9I9.

I8 PRO FO 371/5I2I E 9599/85/44, 7 August i920. Sir H. Samuel (Jerusalem) Personal and Private to Earl Curzon and Prime Minister.

I9 IO L/P\&S/Io/9I4. FO to Samuel, In August I920.

20 PRO FO 37I/5289, s. I27. War Office to Foreign Office, 22 November 1920 .

2I PRO FO 37I/5I2I Parliamentary questions.

22 Ibid.

23 IO L/P\&S/IO/9I4 P6420/20. Interdepartmental Committee meeting, I7 August 1920.

24 Ibid.

25 IO L/P\&S/!=/9II P73I7/20. FO to Robert G. Vansittart, Paris Delegation, 30 September I920.

26 PRO FO 37I/6343. Report on Middle East Conference held in Cairo and Jerusalem. March I2th to 3oth, I92I. With Appendices. Appendix I. (Heretter MEC report).

27 Ibid.

28 Ibid.

29 League of Nations Mandate for Palestine, I2 August I922, http://unispal.un.org/UNISPAL.NSF/o/2FCA2C68Io6 FIIABO5256BCFOo7BF3CB. (5.IO.20I2)

30 Wikisource, "Palestine Mandate", http://en.wikisource.org /wiki/Palestine_Mandate. (I9.I0.20I2)

3I MEC Report, punkt 43.
32 MEC Report, side II3.

33 Wasserstein, op. cit.

34 Brenner, Lenny: The Iron Wall. Zionist Revisionism from Jabotinsky to Shamir. London: Zed Books, I984, s. 72.

35 Shelef, Naday G.: "From 'Both Banks of the Jordan' to the 'Whole Land of Israel'. Ideological Change in Revisionist Zionism, i Israel Studies, vol. 9, nr. I, 2004, s. I26-I27.

36 Ibid.

37 Shelef, op. cit., s. I28. Flere av Heruts forgrunnsfigurer, deriblant statsministrene Menachem Begin og Yitzhak Shamir, hadde sin bakgrunn fra ungdomsbevegelsen Betar.

38 Ved valget 22. januar 20I3 inngikk Likud listesamarbeid med Yisrael Beitenu, og de fikk til sammen 3I av de I20 mandatene i Knesset. Habayit Hayehudi fikk I2 mandater, Hatenua sikret seg seks, og Kadima fikk to.

39 Arens, Moshe: «Palestinians are not wanted in Jordan», i Haartez, I7 april 20I2, http://www.haaretz.com/opinion/ palestinians-are-not-wanted-in-jordan-I.424722. (06.05.2012)

40 Sharon, Ariel with David Chanoff: Warrior: The Autobiography. London: Macdonald, 1989, s. 246.

4I Israel Ministry of Foreign Affairs, “Zionist Leaders: Ze'ev Jabotinsky I880-1940”, http://www.mfa.gov.il/MFA/His tory/Modern\%2oHistory/Centenary\%20of\%20Zionism /Zionist\%2oLeaders-\%20Ze-ev\%20Jabotinsky. (27.I2.20I2)

42 Abu Nowar, Maan: The History Of the Hashemite Kingdom of Jordan. Volume I. The Creation and Development of Trans jordan: 1920-1929. Oxford: Ithaca Press, I989, Ss I49-I52.

43 Israel Ministry of Foreign Affairs, "Separation of Trans jordan (I922)", http://www.mfa.gov.il/MFA/Facts+About+ Israel/Israel+in+Maps/Separation+of+Transjordan+I922.htm. Hentet (I9.II.2OI2)

44 Lawrence Davidson har kommet inn som medforfatter av de siste reviderte utgavene av boken. Han er professor i historie ved West Chester University i Pennsylvania. Den opprinnelige formuleringen når det gjelder Transjordans status, tilhører Goldschmidt.

45 Eugene L. Rogan I999, op. cit.

46 Wilson, Mary C.: King Abdullah, Britain and the making of Jordan. Cambridge: Cambridge University Press, I987, s 49 .

47 Klieman, Aaron S.: Foundations Of British Policy In the Arab World: The Cairo Conference of 1921. Baltimore: The Johns Hopkins Press, I970, SS II4-I2O.

48 Raz, Avi: The Bride and The Dowry. Israel, Jordan and the Palestinians in the Aftermath of the June 1967 War. New Haven: Yale University Press, 20I2, s. 217. 